\title{
An Unmodified Form of the ColE2 Lysis Protein, an Envelope Lipoprotein, Retains Reduced Ability to Promote Colicin E2 Release and Lysis of Producing Cells
}

\author{
By ANTHONY P. PUGSLEY ${ }^{*}$ and STEWART T. COLE \\ Unités de Génétique Moléculaire ${ }^{1}$ et des Applications du Genie Génétique ${ }^{2}$, Institut Pasteur. \\ rue du Dr Roux, Paris 75724, France.
}

(Received 29 December 1986; revised 20 March 1987)

\begin{abstract}
Site-directed mutagenesis was used to replace the codon for the $\mathrm{N}$-terminal cysteine residue of pColE2-P9-encoded mature lysis protein (CelB) by an arginine codon. In contrast to the wildtype CelB protein, the product of the mutated gene, which has an altered signal peptidase cleavage site, was neither processed nor acylated. However, the mutant protein retained sufficient residual activity to cause partial, $\mathbf{M g}^{2+}$-suppressible lysis and could activate envelope phospholipase A1-A2 and promote colicin release, albeit with reduced efficiency compared to the wild-type protein. We propose that the uncleaved signal peptide of the mutant protein acts as the functional equivalent of the fatty acyl groups normally linked to the $\mathrm{N}$-terminal cysteine residue of the wild-type protein, thereby anchoring the protein in the cell envelope where it exerts its various effects.
\end{abstract}

\section{INTRODUCTION}

Colicins initially accumulate in the cytoplasm of producing Escherichia coli cells. Their release into the growth medium is totally dependent upon the expression of the lysis or bacterial release gene located downstream from the colicin structural gene in small, high copy number plasmids such as ColA, ColE1, ColE2, ColE3, ColD, ColN and CloDF13 (Pugsley, 1984; de Graaf \& Oudega, 1986). Lysis gene expression causes activation of a chromosome-encoded phospholipase, with consequent changes in envelope lipid content, permeabilization of the outer membrane, release of colicin and periplasmic proteins (but not of most cytoplasmic or membrane proteins) and $\mathrm{Mg}^{2+}$-suppressible pseudolysis (Pugsley \& Schwartz, 1984). Our characterization of the pColE2-P9 lysis gene $(\mathrm{celB})$ indicated that it codes for a 27 amino acid membrane protein which is synthesized as a precursor with a 19 residue, $\mathrm{N}$-terminal signal peptide (Cole et al., 1985). The sequence of amino acids around the cleavage site in the precursor polypeptide (Ile-Leu-Ser-Ala $\Leftrightarrow$ Cys, where $\Leftrightarrow$ indicates the cleavage site) is similar to that found in precursors of bacterial lipoproteins in which the $\mathrm{N}$-terminal cysteine is modified by ester- and amide-linked fatty acids (Wu, 1985). The sequence of mature CelB protein does not include a hydrophobic transmembrane domain which might anchor it in the cell envelope, although the fatty acyl groups attached to the $\mathrm{N}$-terminal cysteine residue could perform this role, as they do in other lipoproteins.

In the present study, site-directed mutagenesis was used to convert the single cysteine codon, TGT, to CGT coding for arginine, and the effects of this change on CelB protein function were determined.

\section{METHODS}

Bacterial strains, plasmids and growth media. The strain used for most experiments was PAP105 [ $\Delta\left(\right.$ lac-pro) F' pAPIP502 (lacla ${ }^{1}$ SlacZM15 pro ${ }^{+}$Tn 10); Pugsley \& Schwartz, 1983b]. Strain BMH71-18 mutL (Kramer et al., 1984) was the recipient strain for transfection with the products of site-directed mutagenesis

Abbreviation: ITPG, isopropyl $\beta$-D-thiogalactoside. 
experiments. pAPIP226 is described in Pugsley \& Schwartz (1983a). The media used were L broth and M63 minimal medium containing $0.8 \%(\mathrm{w} / \mathrm{v})$ glucose (Miller, 1972), solidified where appropriate with $1.6 \%(\mathrm{w} / \mathrm{v})$ Difco agar. Ampicillin $\left(200 \mu \mathrm{g} \mathrm{ml}^{-1}\right)$, kanamycin $\left(50 \mu \mathrm{g} \mathrm{ml}^{-1}\right)$ and tetracycline $\left(15 \mu \mathrm{g} \mathrm{ml}^{-1}\right)$ were added as required. Colicin production was induced with $0.5 \mu \mathrm{g}$ mitomycin $\mathrm{C} \mathrm{ml}^{-1}$; isopropyl $\beta$-D-thiogalactoside (IPTG; $1 \mathrm{mM})$ and cyclic adenosine monophosphate $(1 \mathrm{mM})$ were used to induce celB or celBI expression in PAP105 derivatives carrying these genes under $l a c Z p$ control in the pUC8 derivatives $\mathrm{pCol} 25$ and $\mathrm{pCol} 26$ respectively (see below).

Oligonucleotide-directed mutagenesis of celB. Site-directed mutagenesis was done on an M13mp8 derivative (Messing \& Vieira, 1982) carrying a $0.38 \mathrm{~kb}$ BglII-Sau3A1 restriction fragment including the celB gene and the transcription terminator of the colicin E2 operon (Pugsley \& Schwartz, 1983b; Cole et al., 1985). A 15 nucleotide mutagenic primer, GCCTGACGTGCAGAC (about 5 pmol), was annealed to the template (about 5 pmol) and extended with the Klenow fragment of DNA polymerase I (1 U) in the presence of T4 DNA ligase (80 U; New England Biolabs), deoxyribonucleoside triphosphates $(0.5 \mathrm{mM})$, ATP $(0.5 \mathrm{mM})$ and DTT $(10 \mathrm{mM})$ at $16^{\circ} \mathrm{C}$ for $16 \mathrm{~h}$, essentially as described by Carter et al. (1985). Samples were used to transfect competent BMH71-18 mutL cells, and appropriate recombinants were identified by plaque hybridization (Benton \& Davis, 1977). Hybridization was done for $1 \mathrm{~h}$ at $20^{\circ} \mathrm{C}$ in a solution containing $6 \times \mathrm{SSC}, 10 \times$ Denhardt's solution (Maniatis et al., 1982), $0.2 \%$ $(\mathrm{w} / \mathrm{v})$ SDS and ${ }^{32} \mathrm{P}$-labelled primer $\left(2 \times 10^{7}\right.$ c.p.m. $)$. Filters were rinsed with $6 \times \mathrm{SSC}(1 \times \mathrm{SSC}$ is $0 \cdot 15 \mathrm{M}-\mathrm{NaCl}$, $0.015 \mathrm{M}$-sodium citrate, $\mathrm{pH} \mathrm{7.0)}$ at $20^{\circ} \mathrm{C}$ and exposed to $\mathrm{X}$-ray film for $1 \mathrm{~h}$ to reveal the background pattern. Stringent washes were then done in $6 \times \mathrm{SSC}$ at $48^{\circ} \mathrm{C}$ (i.e. $2{ }^{\circ} \mathrm{C}$ below the $T_{\mathrm{d}}$ ) and filters reexposed. Plaques still exhibiting positive hybridization signals were purified and used for template preparation. The sequences of all putative mutant celB genes were confirmed by the modified dideoxy method (Biggin et al., 1983) and in all cases the desired transition was found.

Other procedures. General molecular genetic techniques were as described by Maniatis et al. (1982). Basic procedures for labelling proteins with radioactive amino acids, for separating CelB protein by SDS-PAGE in highly cross-linked phosphate-buffered gels, and for lipid analysis were as described previously (Pugsley \& Schwartz, 1983a, 1984; Cole et al., 1985; Pugsley \& Oudega, 1987). [ ${ }^{35}$ S]Cysteine was used at $20 \mu \mathrm{Ci} \mathrm{ml}{ }^{-1}$ $\left(740 \mathrm{kBq} \mathrm{ml}^{-1}\right)$ in medium containing $0.05 \%$ methionine to reduce its metabolism into methionine. Lipoproteins were labelled with $\left[{ }^{3} \mathrm{H}\right]$ palmitate essentially as described by Pugsley et al. (1986). The label was added to cultures in M63 minimal medium containing $0.8 \%$ Casamino acids $10 \mathrm{~min}$ before the IPTG, and labelling was continued for a further $20 \mathrm{~min}$. Total cell proteins were then precipitated with $10 \%(\mathrm{w} / \mathrm{v})$ trichloroacetic acid, and the pellets were resuspended in methanol to remove lipids, then centrifuged, dried and resuspended in sample buffer for SDSPAGE. For extraction with $\mathrm{NaOH}$ (saponification), the samples were resuspended in $1 \mathrm{M}-\mathrm{NaOH}$ in $90 \%(\mathrm{v} / \mathrm{v})$ methanol and incubated for $1 \mathrm{~h}$ at $37^{\circ} \mathrm{C}$. The suspension was then pelleted by centrifugation and resuspended in sample buffer for electrophoresis. Control samples did not receive $\mathrm{NaOH}$. For the fractionation of membranes, cells carrying pCol 25 or pCol26 were labelled with $\left[{ }^{3} \mathrm{H}\right]$ palmitate or $\left[{ }^{35} \mathrm{~S}\right]$ methionine after IPTG induction and then lysed by sonication or repeated freeze-thawing in $50 \mathrm{mM}$ - Tris/ $\mathrm{HCl}(\mathrm{pH} \mathrm{7.4})$ containing $1 \mathrm{mM}-\mathrm{MgSO}_{4}$ and $20 \mu \mathrm{g}$ lysozyme $\mathrm{ml}^{-1}$. Cell debris was then removed by centrifugation at $5000 \mathrm{~g}$ for $10 \mathrm{~min}$, and membranes were pelleted at $130000 \mathrm{~g}$ for $4 \mathrm{~h}$. The membranes were resuspended in $50 \mathrm{~mm}$-Tris $/ \mathrm{HCl}$ containing $1 \mathrm{mM}-\mathrm{MgSO}_{4}$ and extracted with $1 \%(\mathrm{w} / \mathrm{v})$ Triton $\mathrm{X}-100$ for $20 \mathrm{~min}$ at $4{ }^{\circ} \mathrm{C}$. Insoluble proteins were pelleted by high speed centrifugation as above. Triton-soluble proteins were precipitated with $10 \%(\mathrm{w} / \mathrm{v})$ trichloroacetic acid. Duplicate membrane samples were layered onto sucrose gradients $(35-55 \%, \mathrm{w} / \mathrm{v})$ and centrifuged for $66 \mathrm{~h}$ at $130000 \mathrm{~g}$. Fractions from the gradients were supplemented with $10 \mu \mathrm{g}$ bovine serum albumin $\mathrm{ml}^{-1}$ plus $0 \cdot 1 \%(\mathrm{w} / \mathrm{v})$ Triton X100 and then precipitated with $10 \%(w / v)$ trichloroacetic acid. Precipitates were dissolved in sample buffer and examined by SDS-PAGE.

\section{RESULTS}

\section{Site-directed mutagenesis of celB}

To examine the role of acylation of the CelB protein in membrane perturbation, we decided to mutate the $c e l B$ gene to remove the cysteine residue, the putative acylation site. Oligonucleotidedirected mutagenesis was used to convert the cysteine codon into an arginine codon. The mutant allele, celB1, was cloned under the control of the lac promoter in pUC8 (Vieira \& Messing, 1982), and the resulting plasmid named pCol26. A control plasmid, pCol25, carrying the wild-type allele, was constructed in the same way.

\section{Characterization of mutant lysis protein}

Globomycin, a specific inhibitor of lipoprotein signal peptidase (Wu, 1985), was shown to prevent processing of pre-CelB protein (Cole et al., 1985). This was considered as tentative 


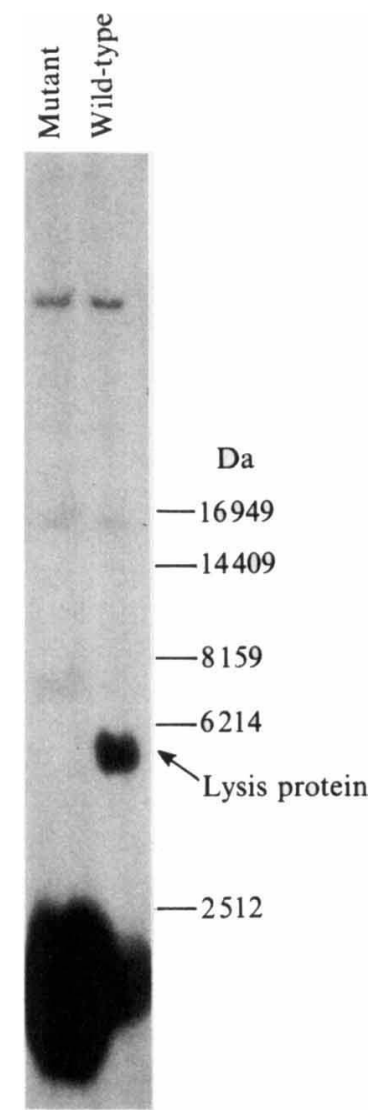

Fig. 1. Identification of wild-type CelB lysis protein encoded by $\mathrm{pCol} 25$ as a lipoprotein by the specific metabolic incorporation of $\left[{ }^{3} \mathrm{H}\right]$ palmitate, and the absence of palmitate incorporation into a protein of the same size in cells carrying pCol26. E. coli cells were induced with IPTG to produce lysis protein which was labelled with $\left[{ }^{3} \mathrm{H}\right]$ palmitate as described in Methods. Proteins were separated in highly cross-linked, phosphate-buffered polyacrylamide gels in the presence of SDS and detected by autoradiography.

evidence for CelB protein being a lipoprotein. Subsequently, a low molecular mass protein which could be labelled with $\left[{ }^{3} \mathrm{H}\right]$ palmitate was specifically detected after expression of the $c e l B$ gene carried by pCol25 (Pugsley et al., 1987). Using cells carrying pCol25 grown in the presence of IPTG, we have shown that the band corresponding to CelB lysis protein in SDSpolyacrylamide gels is not detected after treatment of the samples with $0.1 \mu \mathrm{g}$ proteinase $\mathrm{K} \mathrm{ml}^{-1}$, that about $60 \%$ of the $\left[{ }^{3} \mathrm{H}\right]$ palmitate label is released by treatment with $1 \mathrm{M}-\mathrm{NaOH}$ in $95 \%$ methanol, and that the product co-migrates with authentic CelB protein labelled with ${ }^{14} \mathrm{C}$ labelled amino acids (data not shown). These results provide strong evidence that the $\left[{ }^{3} \mathrm{H}\right]$ palmitate-labelled product is acylated, mature CelB protein, and that about $40 \%$ of the palmitate is attached through an alkali-resistant amide bond. In other lipoproteins, palmitate is the only fatty acid linked via the amide bond to the $\mathrm{N}$-terminal cysteine, while the two fatty acids attached through ester linkages via glycerol are of various types derived from the phospholipid pool (Jackowski \& Rock, 1986). The fact that NaOH-resistant palmitate was found in CelB protein indicates, therefore, that it is processed in the same way as other bacterial lipoproteins.

The IPTG-inducible, low molecular mass protein was not detected in PAP105 (pCol26) cells (Fig. 1). To confirm that celBI was actually expressed, proteins produced by IPTG-induced cells 


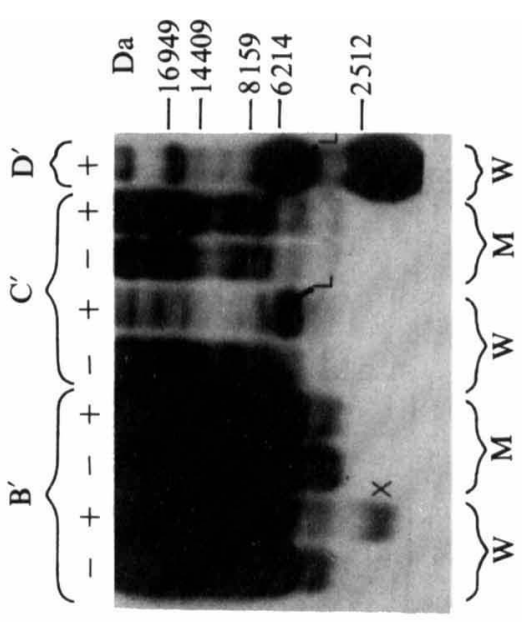

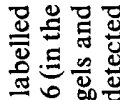

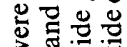

Oे

을

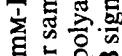

을

政

干这

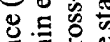

要它

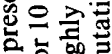

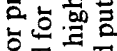

I

․ㅛ

응 중

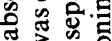

\& ${ }^{3} 0$

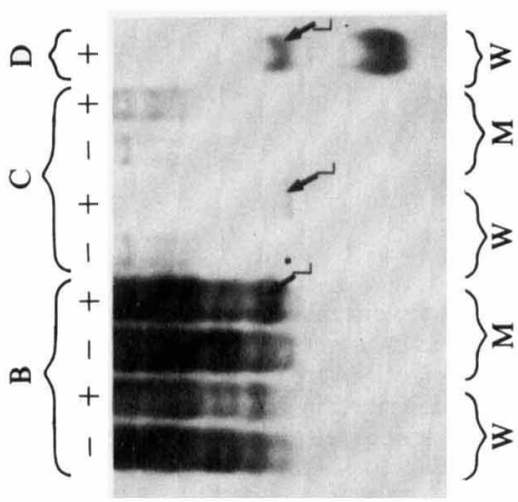

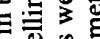

of

.

ถูํำ

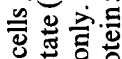

즈르믐

可贾

퐁호

ㅎํㅇ

包焉

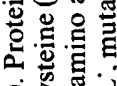

它总严

일

응 옹

论宛

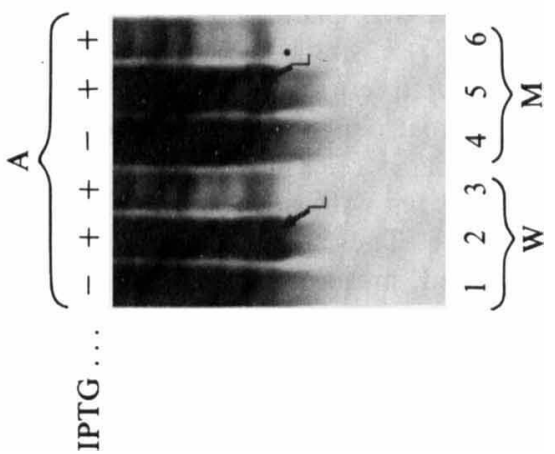

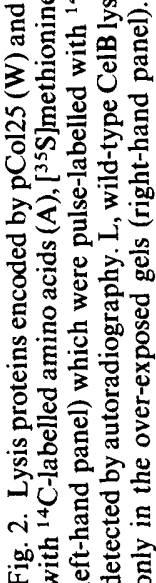




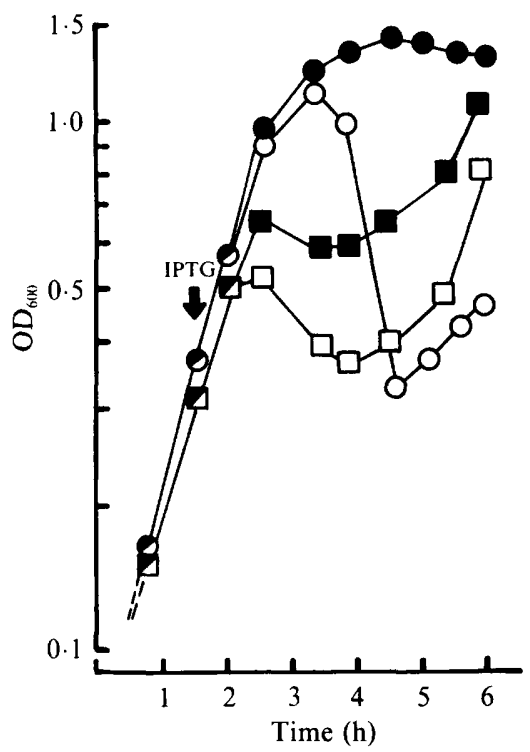

Fig. 3. Effect of production of wild-type (pCol $25 ; \square, \square)$ and mutant $(\mathrm{pCol} 26 ; \bigcirc, \bullet)$ lysis proteins on growth of E. coli K12 in L broth containing 1 mM-IPTG (to induce lysis gene expression) with ( $\square, \theta$ ) or without $\left(\square\right.$, O) $20 \mathrm{mM}-\mathrm{Mg}^{2+}$.

carrying pCol26 were labelled with $\left[{ }^{35}\right.$ S $]$ methionine, $\left[{ }^{35} \mathrm{~S}\right]$ cysteine or ${ }^{14} \mathrm{C}$-labelled amino acids, and these were compared with proteins produced by cells carrying pCol25. Wild-type CelB protein was clearly identified in $\left[{ }^{35} \mathrm{~S}\right]$ cysteine labelled cells and less clearly identified when ${ }^{14} \mathrm{C}$ labelled amino acids were used as the protein label. CelB protein was not detected in ${ }^{35}$ S $]$ methionine-labelled cells (Fig. 2). This last result was expected because the only methionine present in the $c e l B$ gene product is the initiator methionine of the signal peptide, and this is proteolytically removed during processing and maturation of the CelB protein. Wild-type CelB protein was not detected in cells pulse-labelled for $2 \mathrm{~min}$ with $\left[{ }^{35} \mathrm{~S}\right]$ methionine or ${ }^{14} \mathrm{C}$-labelled amino acids (lanes 3 and 6 in Fig. 2A), confirming our previous failure to detect unprocessed, unmodified CelB protein (Cole et al., 1985). The product of the celBI allele could not be detected in $\left[{ }^{35} \mathrm{~S}\right]$ cysteine-labelled cells (as expected from the predicted absence of cysteine from this protein), but was found in extracts from cells labelled with $\left[{ }^{35} \mathrm{~S}\right]$ methionine or ${ }^{14} \mathrm{C}$-labelled amino acids (Fig. 2). The presence of methionine in the celBl gene product, which was apparently larger than wild-type CelB (Fig. 2) protein suggests that the celBl gene product was not processed, and therefore retained its signal peptide.

$\left[{ }^{35} \mathrm{~S}\right]$ Methionine-labelled CelB 1 protein was stable for at least $60 \mathrm{~min}$, indicating that signal peptide cleavage occurred very slowly, if at all. When membranes were separated by isopycnic sucrose gradient centrifugation, $\left[{ }^{35}\right.$ S $]$ methionine-labelled CelB1 protein was found in both the inner membrane protein- and the outer membrane protein-containing fractions. It was, however, totally insoluble in Triton X-100, which normally solubilizes $E$. coli inner membrane proteins (data not shown). $\left[{ }^{3} \mathrm{H}\right]$ Palmitate-labelled wild-type CelB protein was also found in sucrose gradient fractions corresponding to both inner and outer membranes, and was only partially solubilized by Triton X-100 (data not shown), as observed previously with ${ }^{14} \mathrm{C}$-labelled CelB protein (Cole et al., 1985).

\section{Activity of the celB gene product}

Cells carrying pCol25 $\left(\mathrm{celB}^{+}\right)$underwent partial lysis about $35 \mathrm{~min}$ after the addition of IPTG to exponentially growing cultures (Fig. 3), as reported with cells carrying similar plasmids (Pugsley \& Schwartz, 1983b). Cells carrying pCol26 (celBI) also consistently 'lysed' when 


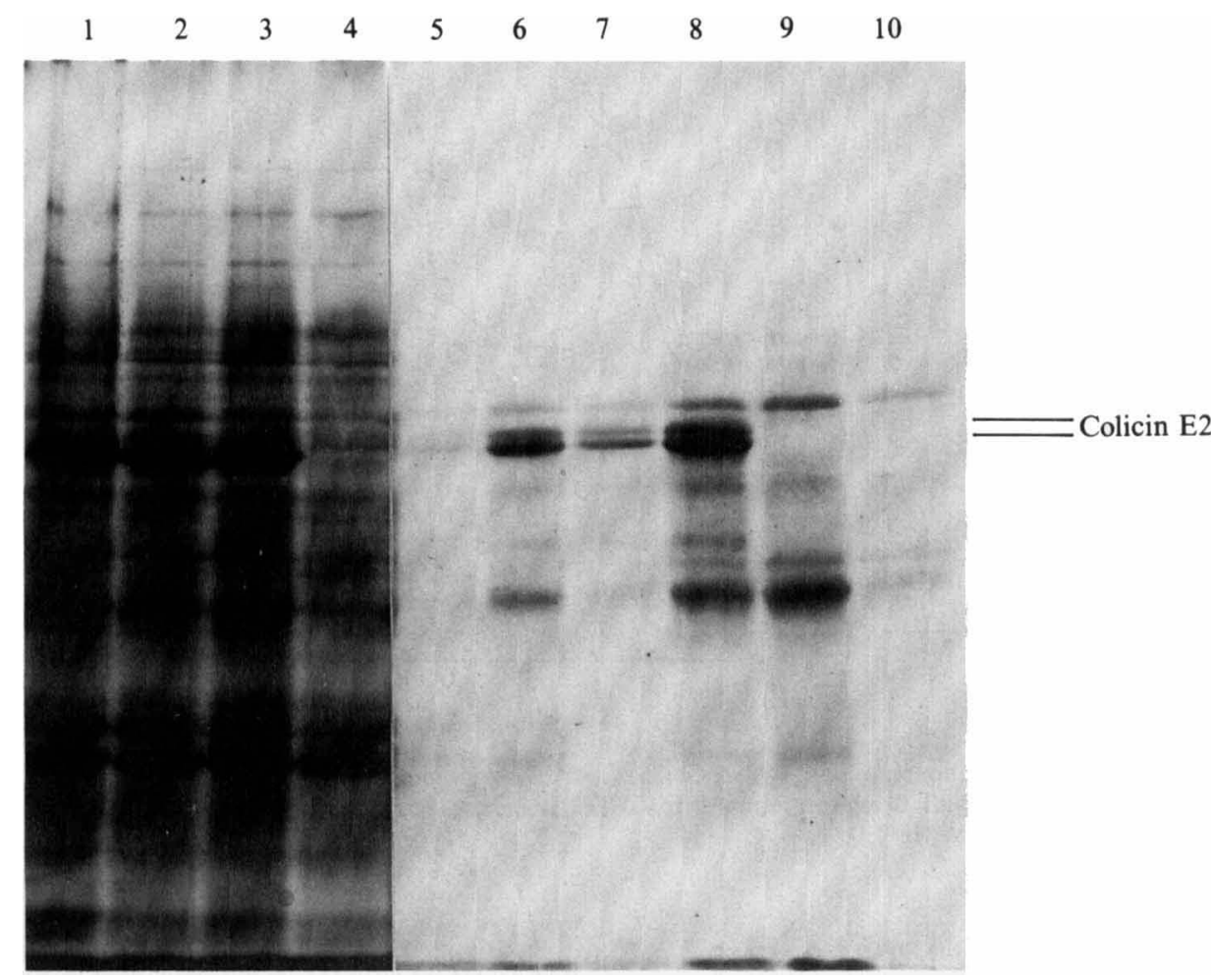

Fig. 4. Complementation of the $c e l B:$ Tn 5 mutation in plasmid pAPIP226 by mutant or wild-type $c e l B$ genes present on plasmid pCol26 and pCol25 respectively. E. coli strain PAP105 carrying the appropriate plasmids was grown to early exponential phase in $\mathrm{L}$ broth. Mitomycin $\mathrm{C}\left(0.5 \mu \mathrm{g} \mathrm{ml}^{-1}\right)$ was added to induce colicin production, and then $1 \mathrm{~h}$ later, IPTG ( $1 \mathrm{mM})$ was added to induce lysis gene expression. Samples, removed from the cultures after a further 60 or $150 \mathrm{~min}$ incubation, were centrifuged to pellet the cells and proteins in the cell-free medium were precipitated with $10 \%(\mathrm{w} / \mathrm{v})$ TCA. The cell pellets and TCA-precipitated proteins were dissolved in Tris/HCl buffer $(50 \mathrm{mM}, \mathrm{pH} 7 \cdot 2)$ containing $2 \%(\mathrm{w} / \mathrm{v}) \mathrm{SDS}$ and $12 \%(\mathrm{v} / \mathrm{v})$ glycerol, heated to $100{ }^{\circ} \mathrm{C}$ for $5 \mathrm{~min}$ and examined by PAGE in Tris glycine-buffered $9 \%(w / v)$ acrylamide gels containing SDS. Lanes 1 and 2, cells carrying pAPIP226 and pCol26 after 60 and 150 min of induction with IPTG respectively; lanes 3 and 4, cells carrying pAPIP226 and pCol25 after 60 and 150 min of induction respectively; lanes 5 and 6 , medium from cells carrying pAPIP226 and pCol25 after 60 and 150 min induction respectively; lanes 7 and 8, medium from cells carrying pAPIP226 and pCol25 after 60 and 150 min respectively; lanes 9 and 10, medium from cells carrying pCol25 (9) or pCol26 (10) only after $150 \mathrm{~min}$ of induction with IPTG. The samples loaded on the gels were equivalent to $200 \mu$ l of culture. Note that the presence of a doublet colicin E2 band is due to proteolysis (Pugsley, 1983) and does not indicate a precursor-mature protein transition.

treated with IPTG, but only after about $100 \mathrm{~min}$ (Fig. 3). In both cases, lysis was almost completely abolished when the medium was supplemented with $20 \mathrm{mM}-\mathrm{MgSO}_{4}$ (Fig. 3). The same effect of $\mathrm{MgSO}_{4}$ was reported for cells expressing the wild-type celB allele under either colicin operon or lac promoter control (Pugsley \& Schwartz, 1984; Pugsley et al., 1987). Since $\mathrm{MgSO}_{4}$ does not prevent lysis caused by other agents (lytic bacteriophage infection, penicillin treatment), this result implies that mutant CelB1 protein induces the same type of partial lysis as is induced by wild-type CelB protein.

In order to study the effects of the mutated $c e l B$ gene on colicin release, plasmids pCol25 or pCol26 were introduced into strain PAP105 carrying pAPIP226 (pColE2-P9 celB::Tn5). This strain produces colicin E2 but does not release it into the medium due to the absence of CelB protein (Pugsley \& Schwartz, 1983a). Plasmids carrying $\mathrm{celB}^{+}$under lac $Z p$ control can complement the celB::Tn5 mutation and promote colicin release (Pugsley \& Schwartz, 1983b; 


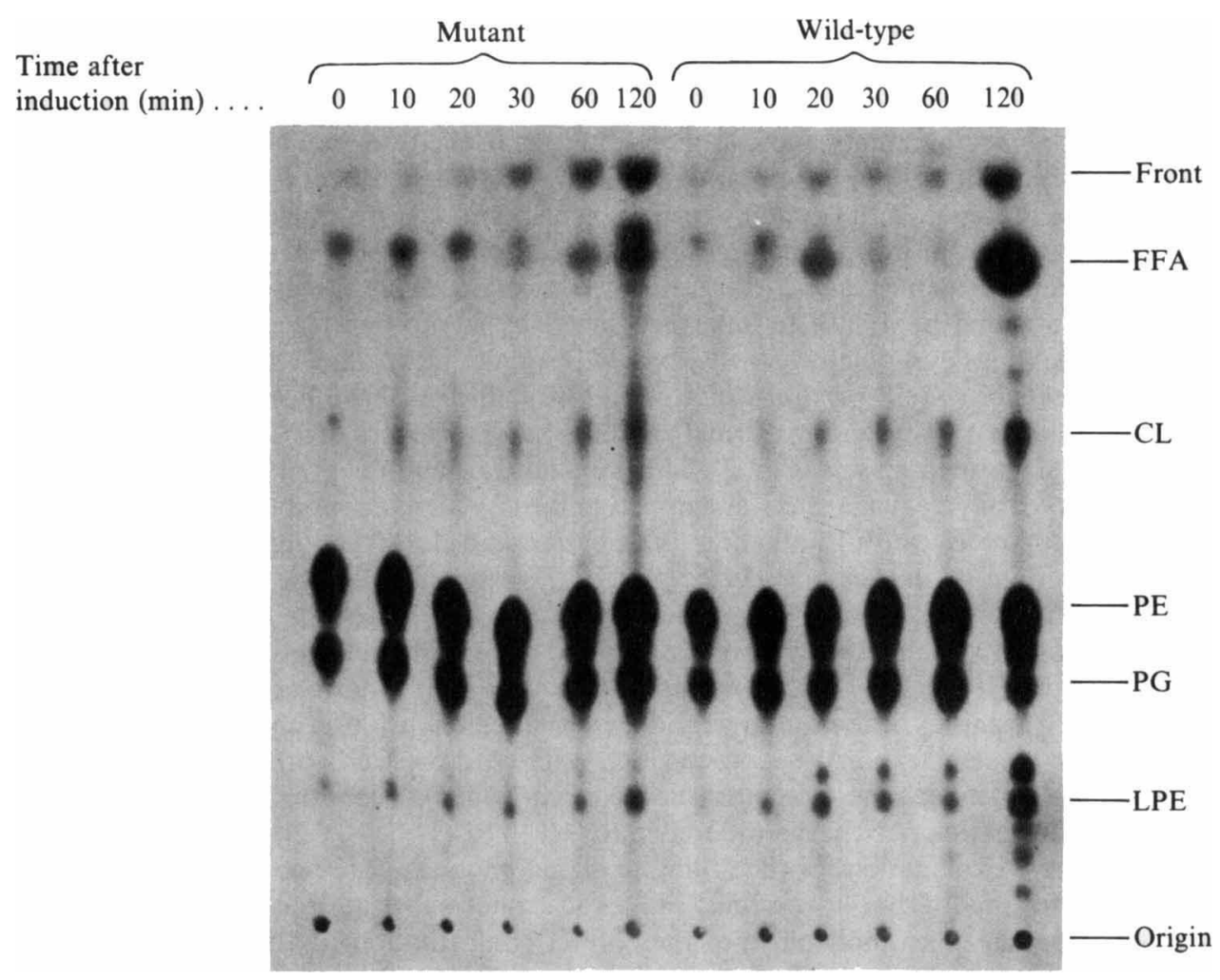

Fig. 5. Changes in lipid composition as a consequence of the induction of mutant or wild-type celB lysis genes in $E$. coli strain PAP105 carrying pCol26 or pCol25 respectively. Cells were grown to early exponential phase in $\mathrm{L}$ broth containing $\left[{ }^{14} \mathrm{C}\right]$ acetate to label lipids, centrifuged, washed and resuspended in fresh medium. IPTG $(1 \mathrm{mM})$ was then added to induce lysis gene expression. Samples were removed from the culture at various times and lipids were extracted from the cells and analysed by thin layer chromatography. FFA, free fatty acids; CL, cardiolipin; PE, phosphatidyl ethanolamine; PG, phosphatidyl glycerol; LPE, lysophosphatidyl ethanolamine. The uneven migration of samples on the left of the plate is an artefact, and does not indicate changes in the structure of the lipids concerned.

this paper Fig. 4). Similarly, the celBI allele in pCol26 also complemented the celB::Tn5 mutation in pAPIP226, although colicin release, like lysis, occurred more slowly than with the wild-type celB allele and substantial amounts of colicin E2 remained cell-associated (Fig. 4). No colicin release occurred until after $4 \mathrm{~h}$ of induction when pUC8 was used in place of pCol 25 or pCol26. We conclude that the $c e l B 1$ gene product is active in promoting colicin release, albeit less-so than the product of the wild-type gene.

Wild-type CelB protein activates envelope phospholipase A1-A2, an essential step in outer membrane permeabilization leading to colicin release (Pugsley \& Schwartz, 1984). CelB1 protein was also observed to activate phospholipase, although changes in envelope phospholipid composition occurred more slowly and were less extensive than with the wild-type CelB protein (Fig. 5). No changes in phospholipid composition were induced by expression of either mutant or wild-type CelB protein in a strain carrying a mutation in pldA, the structural gene for detergent-resistant phospholipase A1-A2 (data not shown; see Pugsley and Schwartz, 1984).

\section{DISCUSSION}

Several features of the wild-type CelB lysis protein could contribute to the activation of phospholipase and to the specific export of colicin across the inner membrane. These include the 
removal of the signal peptide, the apparent high degree of stability of the signal peptide after its removal from wild-type pre-CelB (Pugsley \& Schwartz, 1983a, $b$; this paper Fig. 2), the conversion of the $\mathrm{N}$-terminal cysteine to glyceryl-cysteine, the addition of fatty acids by ester linkages to the glycerol moiety and by amide-linkages to the free amino group of the cysteine, and the membrane location of the mature protein. Most of these features of the CelB protein depend on the presence of the cysteine residue at position +1 ; its replacement represented an obvious approach to probing structure-function relationships.

In changing the cysteine residue to arginine, we hoped to replace the cleavage site recognized by lipoprotein signal peptidase by one recognized by signal peptidase I (also called leader peptidase; see Pugsley \& Schwartz, 1985). This would have allowed us to determine the biological effects of a CelB protein which would probably not have been anchored in the cell envelope by its fatty acyl groups (see Introduction). However, pre-CelB1 protein was not processed by signal peptidase I (Fig. 2). This may have been due to the fact that the sequence around the potential cleavage site was not recognized by signal peptidase. Arginine is the Nterminal residue of $E$. coli $\mathrm{K} 12$ alkaline phosphatase and the structurally equivalent lysine is present at position +1 in several exported proteins (Watson, 1984). A detailed survey of charge distributions in precursors of a large number of exported or secreted proteins has shown, however, that prokaryotic exported proteins tend to have acidic residues just after the cleavage site. von Heijne (1986) suggsts that a dipolar structure with a positive net charge difference between the $\mathbf{N}$ terminus of the signal peptide and the region just after the cleavage site may be important for efficient export and processing. Wild-type pre-CelB protein has a net charge difference of +2 between these regions (see Cole et al., 1985). The introduction of Arg in place of Cys +1 reduces this net charge difference to +1 .

An alternative explanation for the failure of signal peptidase I to process pre-CelB1 protein may be that its small size (46 residues) makes it a poor substrate for this enzyme, possibly because the precursor cannot fold into the correct conformation to allow signal peptidase I access to the cleavage site.

CelB1 protein retains only two of the characteristic features of the wild-type protein, namely its membrane location and the stability of the signal peptide, which, in the mutant, remains attached to the mature part of the polypeptide. The fact that the mutant protein retains a low level of activity for all the functions known for the mature wild-type CelB protein (promotion of lysis, translocation of colicin E2 across the cytoplasmic membrane and activation of phopholipase A1-A2), indicates that the modified cysteine residue of mature wild-type CelB protein is not completely indispensable for any of these phenomena, although the wild-type, fatty acylated protein is clearly more effective than the mutant, unmodified derivative lacking this cysteine residue.

One possible explanation for at least some effects of $c e l B$ expression is that the accumulation of the apparently stable signal peptide (Pugsley \& Schwartz, 1983a,b) in the cell envelope perturbs membrane structure sufficiently to activate phospholipase. The signal peptide of the major 'Braun' lipoprotein is unstable, and is rapidly degraded after cleavage from prelipoprotein (Ichihara et al., 1986; Novak et al., 1986). Mutant CelB lysis protein with its unprocessed signal peptide might be expected to have the same effect as the processed but stable signal peptide of wild-type CelB protein.

According to current models for signal-peptide-dependent export of envelope proteins in $E$. coli (Pugsley \& Schwartz, 1985; Wickner \& Lodish, 1985), the signal peptide inserts into and remains within the cytoplasmic membrane. Mature lysis protein is found in both inner and outer membranes (Oudega et al., 1984; Cole et al., 1985; this paper). Therefore, if current models also apply to lysis protein export, the signal peptide would be expected to remain in the cytoplasmic membrane whatever the final location of the mature, acylated lysis protein, and mutant, unacylated lysis protein should remain anchored in the inner membrane by its unprocessed signal peptide. Our cell fractionation data indicated, however, that mutant lysis protein was also found in both inner and outer membranes. This implies that the signal peptide can reach the outer membrane, a possibility not previously considered likely even though junctions between the inner and outer membranes have often been proposed as sites of protein export in Gram- 
negative bacteria (see Pugsley \& Schwartz, 1985). This interpretation relies on the accurate prediction of lysis protein location by cell fractionation techniques. Tommassen (1986) has already cited several situations in which such techniques are not reliable, and we have found that lipoprotein localization cannot always be accurately determined by physical fractionation (unpublished data). Thus, we believe that other methods should be sought to determine the location of wild-type and mutant lysis proteins in the cell. On the other hand, we note that phospholipase A1-A2 is an outer membrane protein (Nishijima et al., 1977), and would be expected, therefore, to be activated by agents (e.g. mutant lysis protein) affecting the outer membrane.

One other result deserves some comment; namely, the observation that wild-type CelB protein seems to be much more abundant than was previously assumed (see Pugsley \& Schwartz, $1983 a, b)$. Note, in particular, that CelB protein is by far the most intensely $\left[{ }^{3} \mathrm{H}\right]$ palmitatelabelled lipoprotein (Fig. 1). If this reflects the abundance of the protein, it may be possible to purify sufficient amounts to conduct in vitro studies on its action.

We are grateful to M. Schwartz for helpful discussions. The work was supported by the Institut Pasteur, by CNRS grants UAO41149 and ATPCP96, by MRT grant 82V1279 and by the Fondation pour la Recherche Médicale.

\section{REFERENCES}

BENTON, W. D. \& DAvis, R. W. (1977). Screening of $\lambda g t$ recombinant clones by hybridization to single plaques in situ. Science 196, 180-182.

Biggin, M. D., Gibson, T. J. \& Hong, G. (1983). Buffer gradient gels and ${ }^{35} \mathrm{~S}$ label as an aid to rapid DNA sequence determination. Proceedings of the National Academy of Sciences of the United States of America 80, 3963-3965.

Carter, P., Bedouelle, H. \& Winter, G. (1985). Improved oligonucleotide site-directed mutagenesis using M13 vectors. Nucleic Acids Research 12, 44314443 .

Cole, S. T., Saint-Joanis, B. \& Pugsley, A. P. (1985). Molecular characterization of the colicin E2 operon and identification of its products. Molecular and General Genetics 198, 465-472.

DE GraAF, F. K. \& Oudega, B. (1986). Production and release of cloacin DF 13 and related colicins. Current Topics in Microbiology and Immunology 125, 183-205.

voN Heijne, G. (1986). Net N-C charge imbalance may be important for signal sequence function in bacteria. Journal of Molecular Biology 192, 287-290.

ICHIHARa, S., SuzUkI, T., SuzUki, M. \& Mizushima, S. (1986). Molecular cloning and sequencing of the sppA gene and characterization of the encoded protease IV, a signal peptide peptidase of Escherichia coli. Journal of Biological Chemistry 261, 9405-9411.

JACKOWSKI, S. \& RoCK, C. O. (1986). Transfer of fatty acids from the 1-position of phosphatidylethanolamine to the major outer membrane lipoprotein of Escherichia coli. Journal of Biological Chemistry 261, 11328-11333.

Kramer, B., Kramer, W. \& Fritz, H.-J. (1984) Different base/base mismatches are corrected with different efficiencies by the methyl-directed DNA mismatch repair system of $E$. coli. Cell 38, 879-887.

Maniatis, T., Fritsch, E. F. \& Sambrook, J. (1982). Molecular Cloning, a Laboratory Manual. Cold Spring Harbor, NY: Cold Spring Harbor Laboratory.

Messing, J. \& Vieira, J. (1982). A new pair of M13 vectors for selecting either DNA strand of double digest restriction fragments. Gene 19, 269-276.
Miller, J. H. (1972). Experiments in Molecular Genetics. Cold Spring Harbor, NY: Cold Spring Harbor Laboratory.

Nishijima, M., Nakaike, S., Tamori, Y. \& Nojima, S. (1977). Detergent-resistant phospholipase A of Escherichia coli K-12. Purification and properties. European Journal of Biochemistry 73, 115-124.

Novak, P., RAY, P. H. \& DEV, I. K. (1986). Localization and purification of two enzymes from Escherichia coli capable of hydrolyzing a signal peptide. Journal of Biological Chemistry 261, 420427.

Oudega, B., Ykema, A., Stegehuis, F. \& de Graaf, F. K. (1984). Detection and subcellular localization of mature protein $\mathrm{H}$, involved in excretion of cloacin DF13. FEMS Microbiology Letters 22, 101108.

Pugsley, A. P. (1983). Colicin E4-CT9 is proteolytically degraded after discharge from producing cells in liquid culture. Journal of General Microbiology 129, 833-840.

Pugsley, A. P. (1984). The ins and outs of colicins. Microbiological Sciences 1, 168-175.

Pugsley, A. P. \& OudegA, B. (1977). Methods for studying colicins and their plasmids. In Plasmids, A Practical Approach, pp.105-161. Edited by K. Hardy. Oxford: IRL Press.

Pugsley, A. P. \& Schwartz, M. (1983a). A genetic approach to the study of mitomycin-induced lysis of Escherichia coli K-12 strains which produce colicin E2. Molecular and General Genetics 190, 366372.

Pugsley, A. P. \& Schwartz, M. (1983b). Expression of a gene in a 400 base-pair fragment of the colicin plasmid ColE2-P9 is sufficient to cause host cell lysis. Journal of Bacteriology 156, 109-114.

Pugsley, A. P. \& Schwartz, M. (1984). Colicin E2 release: lysis, leakage or secretion? Possible role of a phospholipase. EMBO Journal 3, 2393-2397.

Pugsley, A. P. \& Schwartz, M. (1985). Protein export and secretion by bacteria. FEMS Microbiological Reviews 1, 3-39. 
Pugsley, A. P., Chapon, C. \& Schwartz, M. (1986). Extracellular pullulanase of Klebsiella pneumoniae is a lipoprotein. Journal of Bacteriology 166, 10831088.

Pugsley, A. P., D'Enfert, C. \& Cole, S. T. (1987). Protein secretion by Escherichia coli: colicins and pullulanase. In Proceedings of the Fifth International Symposium on the Genetics of Industrial Microorganisms B, 431-438.

TOMMASSEN, J. (1986). Fallacies of E. coli fractionations and consequences thereof for protein export models. Microbial Pathogenicity 1, 225-228.
Vieira, J. \& Messing, J. (1982). The pUC plasmids, an M13mp7 derived system for insertion mutagenesis and sequencing with synthetic universal primers. Gene 19, 259-268.

WATSON, M. E. E. (1984). Compilation of published signal sequences. Nucleic Acids Research 12, 51455159.

WICKNER, W. T. \& LODISH, H. F. (1985). Multiple mechanisms of protein insertion into and across membranes. Science 230, 400-407.

WU, H. (1985). Biogenesis of membrane lipoproteins in bacteria. Microbiology 1985, 303-307. 